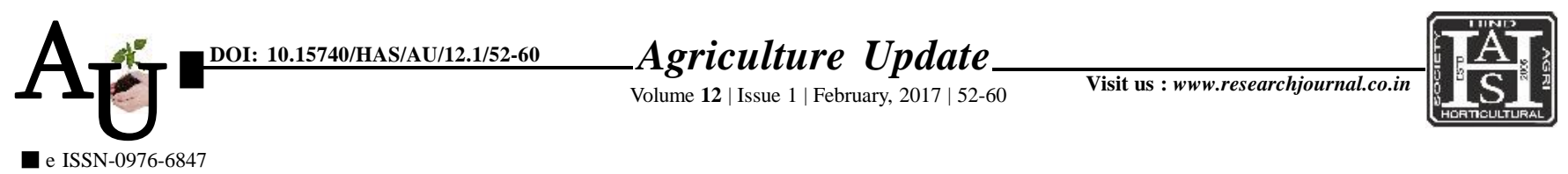

\title{
Research Article: Profile and constraints of orange growers in adoption of soil testing techniques in Amravati district
}

\author{
YOGITA WANKHEDE, N.M. KALE, P.P. BHOPLE AND N.P. JANGWAD
}

Article Chronicle: Received : 03.12.2016; Revised : 16.12.2016; Accepted : 23.12.2016

KeY Words: Profile, Constrains, Soil testing Techniques, Adoption

Author for correspondence :

\section{N.M. KALE}

Department of Extension Education, Post Graduate Institute, Dr. Panjabrao Deshmukh Krishi Vidyapeeth, AKOLA (M.S.) INDIA Email:nmkale1964 @ gmail.com

See end of the article for authors' affiliations
SUMMARY : The research study was conducted in Warud and Morshi talukas of Amravati district (Vidarbha region) of Maharashtra with exploratory design of the social research during 2015-16. Multistage sampling method was used for the study. Total 100 orange orchards owner having productive orange trees were the respondents for the study. The study revealed that 58.00 per cent orange growers have tested their orchard soil. Majority of orange growers had area under orange orchards upto 2.00 ha. Majority 67.00 per cent respondents have not availed the employment guarantee scheme of government for plantation of orange orchard; they have planted the orchard by spending their own money. Majority of respondents have to travel distance between 51 to $100 \mathrm{~km}$ from their villages to reach at soil testing laboratory. Maximum 63.00 per cent of orange growers have used drip as a method of irrigation. Exactly half $(50.00 \%)$ of the respondents kept medium level of extension contact with extension agencies for seeking information. Majority (87.00\%) orange orchards affected by dieback disease, majority of respondents have used the State department soil testing laboratories as soil testing agency for testing of orchards soil. More than half (57.00\%) orange growers faced the constraints of lack of knowledge about soil testing and 47.00 per cent orange growers faced the constraints of lack of technical skill about soil testing technique, as technical constraints. As regard to situational constraints, 73.00 per cent respondents faced problem of delay in soil test report. It could be concluded that the analysis of these constraints would call for the attention of the administrators of Government, Department of Agriculture of Maharashtra and other concerned departments for planning systematic efforts to encountered these constraints will go long way for the Development of Agriculture in general and Horticulture in particular.

How to cite this article : Wankhede, Yogita, Kale, N.M., Bhople, P.P. and Jangwad, N.P. (2017). Profile and constraints of orange growers in adoption of soil testing techniques in Amravati district. Agric. Update, 12(1): 5260; DOI : 10.15740/HAS/AU/12.1/52-60. 